\title{
Low dose captopril in the treatment of severe refractory hypertension associated with renal failure
}

\author{
G. M. BELL \\ M.R.C.P. \\ M. L. WATSON \\ M.R.C.P. \\ A. DOIG \\ A. L. MUIR \\ F.R.C.P. (Ed.) \\ F.R.C.P. (Ed.) \\ R. J. WINNEY \\ F.R.C.P. (Ed.)
}

Department of Medicine and Medical Renal Unit, The Royal Infirmary, Edinburgh EH3 9YW

\begin{abstract}
Summary
Six patients with severe refractory hypertension and chronic renal failure were treated with a low dose of captopril (mean daily dose $75 \mathrm{mg}$ ) in combination with dietary sodium restriction, frusemide and either metoprolol, labetalol or prazosin. Sustained control of blood pressure was achieved in all six patients. Adverse effects noted were severe hyperkalaemia (2 patients), skin rashes (2 patients) and taste disturbance (1 patient).
\end{abstract}

\section{Introduction}

The angiotensin-I converting inhibitor, captopril, has been used to control severe hypertension in doses of up to $450 \mathrm{mg}$ daily' (Brunner et al., 1978; Brunner et al., 1979). A number of adverse effects have been reported with the drug (Atkinson et al., 1980) and in view of its renal excretion (Kripalani et al., 1980) a reduced dosage regime has been recommended for patients with renal impairment.

We report six patients with severe refractory hypertension and chronic renal failure whose blood pressure has been effectively controlled by the use of a low dose of captopril (mean daily dose $75 \mathrm{mg}$ ) in combination with other antihypertensive agents.

\section{Patients and methods}

Details of the patients and their underlying renal disease are given in Table 1. All patients suffered from severe refractory hypertension complicated recently by grade III hypertensive retinopathy and impaired renal function. None of the patients had adequately controlled blood pressure while in hospital on treatment with a combination of various different drugs in the maximum tolerated dosage or at the expense of intolerable adverse effects, and dietary sodium restriction $(100 \mathrm{mmol} / \mathrm{day}$ in all patients except patient 4 who was receiving 50 $\mathrm{mmol} /$ day).

All patients gave informed consent before entering the study.

Blood pressure (mean of 2 values) was recorded by an experienced observer after $10 \mathrm{~min}$ in the supine position and again after 2 min standing. Readings were obtained by an ordinary clinical sphygmomanometer using phase IV as the diastolic phase. Previous drug therapy was discontinued $24 \mathrm{hr}$ before captopril was introduced. Blood samples for measurement of plasma renin activity (PRA) were obtained after overnight fasting and recumbency immediately before captopril therapy. Captopril was started in a dose of $12.5 \mathrm{mg}$ orally and gradually increased to the maximum daily dose which was dependent on the patient's renal function. Brunner $e t$ al. (1979) noted satisfactory blood pressure control using a twice daily captopril regime. Captopril in this present study was given orally in a divided daily dose at 08.00 and 18.00 hours. This was $50 \mathrm{mg}$ a day in patients 1,3 and 4 (plasma creatinine greater than $350 \mu \mathrm{mol} /$ litre) and $100 \mathrm{mg}$ a day in patients 2,5 and 6 (plasma creatinine 200-350 $\mu \mathrm{mol} /$ litre). Patients were discharged from hospital when their blood pressure was stable at an acceptable level.

The dramatic, but short-lived, fall in blood pressure in all six patients following the first dose of captopril $(12.5 \mathrm{mg})$ showed no relation to the PRA. The hypotensive response to subsequent doses was smaller and after three days therapy with captopril in the maximum dosage, frusemide $40 \mathrm{mg}$ oral b.d. was added. However, at 7 days labetalol or metoprolol was added to an unchanged dose of captopril to improve blood pressure control in 5 of the patients. Prazosin was added in patient 4 , beta-adrenoceptor blockers being contraindicated due to severe bronchial asthma.

Wilcoxon's Rank Sum Test was used throughout. 
TABLE 1. Patient details

\begin{tabular}{|c|c|c|c|c|c|}
\hline Patient & Age/Sex & Diagnosis & $\begin{array}{c}\text { Plasma renin } \\
\text { activity } \\
\text { [ng/ml/hr] }\end{array}$ & $\begin{array}{l}\text { Previous drugs* } \\
\text { and daily dose [mg] }\end{array}$ & $\begin{array}{l}\text { Present drugs and } \\
\text { daily dose [mg] }\end{array}$ \\
\hline 1 & $48 / \mathrm{M}$ & $\begin{array}{l}\text { Essential } \\
\text { hypertension }\end{array}$ & $16 \cdot 8$ & $\begin{array}{l}\text { FR(80) LAB(1200) } \\
\text { HYD(200) PR(16) }\end{array}$ & $\begin{array}{l}\text { CAP(50) LAB(600) } \\
\text { FR(80) }\end{array}$ \\
\hline 2 & $64 / M$ & $\begin{array}{l}\text { Chronic } \\
\text { glomerulonephritis }\end{array}$ & 1.6 & $\begin{array}{l}\text { PR(12) DEB(60) } \\
\text { FR(80) LAB(800) }\end{array}$ & $\begin{array}{l}\text { CAP(100) LAB(600) } \\
\text { FR(80) }\end{array}$ \\
\hline 3 & $32 / \mathrm{M}$ & $\begin{array}{l}\text { Chronic } \\
\text { glomerulonephritis }\end{array}$ & $6 \cdot 1$ & $\begin{array}{l}\text { MET(200) HYD(200) } \\
\text { PR(8) FR(80) }\end{array}$ & $\begin{array}{l}\text { CAP(50) MET(100) } \\
\text { FR(120) }\end{array}$ \\
\hline 4 & $49 / \mathrm{F}$ & $\begin{array}{l}\text { Essential } \\
\text { hypertension }\end{array}$ & $15 \cdot 1$ & $\begin{array}{l}\text { METH(2000) HYD(200) } \\
\operatorname{DEB}(40)\end{array}$ & $\begin{array}{l}\text { CAP(50) PR(6) } \\
\text { FR(80) }\end{array}$ \\
\hline 5 & $38 / \mathrm{F}$ & $\begin{array}{l}\text { Chronic } \\
\text { pyelonephritis }\end{array}$ & $6 \cdot 3$ & $\begin{array}{l}\text { FR(80) MET( } 800) \\
\text { HYD(200) }\end{array}$ & $\begin{array}{l}\text { CAP(100) MET(800) } \\
\text { FR(80) }\end{array}$ \\
\hline 6 & $52 / \mathrm{M}$ & $\begin{array}{l}\text { Essential } \\
\text { hypertension }\end{array}$ & $2 \cdot 3$ & $\begin{array}{l}\text { FR(160) MET(400) } \\
\text { HYD }(200)\end{array}$ & $\begin{array}{l}\text { CAP(100) MET(400) } \\
\text { FR(160) }\end{array}$ \\
\hline $\begin{array}{l}R=f \\
Y D=r\end{array}$ & $\begin{array}{l}\text { mide; } \\
\text { alazine; }\end{array}$ & $\begin{array}{l}\text { METH = methyldopa; } \\
\text { CAP = captopril; }\end{array}$ & $\begin{array}{l}\mathrm{LAB}=\mathrm{la} \\
\mathrm{DEB}=\mathrm{de}\end{array}$ & $\begin{array}{l}\text { PR }=\text { pra } \\
M E T=\text { me }\end{array}$ & $\begin{array}{l}\text { n; } \\
\text { olol. }\end{array}$ \\
\hline
\end{tabular}

\section{Results}

At follow-up two values of erect and supine blood pressure were obtained immediately before the 08.00 hr captopril dose and again at 12.00, 16.00 and 17.55 hr. The mean of these 8 supine values was recorded as the respective follow-up blood pressure. The most recent in-patient blood pressures on previous therapy before the start of captopril treatment (Table 2) were compared with those obtained after one month, 3 months and 6 months on the captopril combination. There was a significant reduction in both systolic $(P<0.01)$ and diastolic $(P<0.01)$ pressure without evidence of a postural fall in pressure. There was no suggestion of loss of blood pressure control during each $24 \mathrm{hr}$ period.

Plasma creatinine increased in all patients during the 3 months before captopril on previous therapy but remained unchanged during the 6 months treatment with captopril (Table 2). Mean ( \pm s.d.) plasma creatinine at three months and one week before captopril and 1, 3 and 6 months after captopril was respectively $372 \pm 240 \mu \mathrm{mol} /$ litre, $493 \pm 262$ $\mu \mathrm{mol} /$ litre, $514 \pm 266 \mu \mathrm{mol} /$ litre, $523 \pm 267 \mu \mathrm{mol} /$ litre and $529 \pm 252 \mu \mathrm{mol} /$ litre.

All patients showed an increase in plasma potassium by the end of the second month of therapy (mean increase $1.2 \mathrm{mmol} /$ litre). Severe hyperkalaemia (plasma potassium greater than $6 \mathrm{mmol} / \mathrm{litre}$ ) occurred in two patients both during the second month of treatment. This initially required oral calcium resonium but latterly has been controlled on dietary potassium restriction alone. Within patient analysis showed no relationship between plasma creatinine and plasma potassium levels.
A transient, itchy maculopapular rash developed in two patients. This responded to calamine lotion in one case, but in the other an antihistamine was required. One patient complained of a marked disturbance of taste during the third month of therapy. There were no changes in the white celf count, platelet count and $24 \mathrm{hr}$ urinary protein loss iff all patients during the 6-month treatment period.

After this 6-month study period we attempted to reduce the captopril dosage in two patients both with a plasma creatinine greater than $350 \mu \mathrm{mol} /$ litre from a divided daily dose of $50 \mathrm{mg}$ of captopril firstly to 25 $\mathrm{mg}$ on alternate days and then to $25 \mathrm{mg}$ once a day. This resulted in a temporary loss of blood pressure control in both patients at both the single and alternate day dosage which came under satisfactory control on returning to the original $25 \mathrm{mg}$ twice a day regime.

\section{Discussion}

Captopril in a daily dose of $450 \mathrm{mg}$ in combination with frusemide has proved to be effective therapy for severe refractory hypertension (Brunner et al., 1979; Atkinson et al., 1980). Although the renin-angiotensin system is effectively inhibited by a single dose of less than $25 \mathrm{mg}$ of captopril, the hypotensive effect is short-lived (Swartz et al., 1980), as captopril is thought to be cleared from the circulation within $6 \mathrm{hr}$ (Kripalani et al., 1980). The high renal clearance $(70 \%)$ of the drug suggests that accumulation is liable to occur in patients with renal failure and in view of the adverse effects associated with captopril (Atkinson et al., 1980) a reduced dosage regime has been recommended for use in such patients. 
This study demonstrates that in patients with renal failure significantly improved blood pressure control can be achieved when a low dose of captopril is combined with other therapy which may either increase the dependency of the blood pressure on the renin-angiotensin system, e.g. sodium restriction and diuretics (Oelkers et al., 1974) or act via other antihypertensive mechanisms. Until a plasma captopril assay becomes available and the therapeutic levels of captopril are clearly defined, this captopril regime provides effective blood pressure control in patients with renal failure and severe hypertension which has previously failed to respond to a wide range of other antihypertensive drugs. The possible accumulation effect of captopril in these patients makes it difficult to estimate the antihypertensive action of the beta-adrenoceptor blocking drugs used in this study. However, considering the previous refractory hypertension of these patients while receiving large doses of beta-blocking drugs we suggest that the improved blood pressure control was mainly the result of low dose captopril in conjunction with frusemide and dietary sodium restriction.

Captopril can cause a number of severe adverse effects. White et al. (1980) noted that in patients with renal impairment receiving $\mathbf{4 5 0} \mathrm{mg}$ of captopril a day severe hyperkalaemia exceeding $6 \mathrm{mmol} /$ litre occurred in 3 patients. Our data indicate that hyperkalaemia remains a particular problem in patients with chronic renal failure despite using low dose captopril. However, the blood dyscrasias (Gavras et al., 1981; El Matri et al., 1981) and nephropathy (Hoorntje et al., 1980) previously reported after standard dose captopril therapy have not, to date, developed in any of our patients.

\section{Acknowledgment}

We thank Dr P. V. Pigott and Dr W. Weston-Davies (Squibb, Europe) for supplies of captopril.

\section{References}

AtKinson, A.B., Brown, J.J., Lever, A.F. \& Robertson, J.I.S. (1980) Combined treatment of severe intractable hypertension with captopril and diuretic. Lancet, ii, 105.

Brunner, H.R., Gavras, H., Waeber, B., Kershaw, G.R., TuRINI, G.A., VUKOVICH, R.A., MCKINSTRAY, D.N. \& GAVRAS, I. (1979) Oral angiotensin converting enzyme inhibitor in long-term treatment of hypertensive patients. Annals of Internal Medicine, 90, 19.

BrunNer, H.R., WAeber, B., WaUters, J.P., TURINI, G., MCKINSTRY, D. \& GAVRAS, H. (1978) Inappropriate renin secretion unmasked by captopril (SQ 14225) in hypertension of chronic renal failure. Lancet, ii, 704 .

El Matri, A., Larabi, M.S., Kechrid, C., Belkahia, C. \& Ben AYED, H. (1981) Fatal bone marrow suppression associated with captopril. British Medical Journal, 283, 277.

Gavras, I., GrafF, L.G., Rose, B.D., MCKenna, M.M., BrunNer, H.R. \& GAVRAS, H. (1981) Fatal pancytopenia associated with the use of captopril. Annals of Internal Medicine, 94, 58.

HoORNTJe, S.J., Kallenberg, C.A.M., WeEning, J.J., DonKer, A.B.J.M. The, T.H. \& Hoedemaeker, P.J. (1980) Immune complex glomerulopathy in patients treated with captopril. Lancet, i, 1212.

Kripalani, K.J., McKinstry, D.N., Singhvi, S.M., Willard, D.A., Vukovich, R.A. \& Migdalof, B.H. (1980) Disposition of captopril in normal subjects. Clinical Pharmacology and Therapeutics, 27, 636.

OelKers, W., Brown, J.J., Fraser, R., LeVer, A.F., Morton, J.J. \& ROBERTSON, J.I.S. (1974) Sensitisation of the adrenal cortex to angiotensin II in sodium deplete man. Circulation Research, 34, 69.

SwartZ, S.L., Williams, G.H., Hollenberg, N.K., LeVin, L., DLUHY, R.G. \& MOORE, T.J. (1980) Captopril induced changes in prostaglandin production: relationship to vascular responses in normal man. Journal of Clinical Investigation, 65, 1257.

White, N.J., RaJagopalan, B., Yahaya, H. \& Ledingham, J.G.G. (1980) Captopril and frusemide in severe drug-resistant hypertension. Lancet, ii, 108.

TABLE 2. Blood pressure (BP) $(\mathrm{mmHg})$ and plasma creatinine ( $\mu \mathrm{mol} /$ litre) before and after captopril treatment

\begin{tabular}{ccccc}
\hline $\begin{array}{c}\text { Patient } \\
\text { no. }\end{array}$ & $\begin{array}{c}\text { 3 months pre-captopril } \\
\text { Plasma } \\
\text { creatinine }\end{array}$ & $\begin{array}{c}\text { Out-patient } \\
\text { BP }\end{array}$ & $\begin{array}{c}\text { 1 week pre-captopril } \\
\text { Plasma } \\
\text { creatinine }\end{array}$ & $\begin{array}{c}\text { In-patient } \\
\text { BP }\end{array}$ \\
\hline 1 & 520 & $230 / 150$ & 675 & $200 / 130$ \\
2 & 260 & $180 / 120$ & 320 & $170 / 115$ \\
3 & 800 & $160 / 110$ & 830 & $200 / 110$ \\
4 & 208 & $220 / 140$ & 670 & $205 / 145$ \\
5 & 211 & $220 / 120$ & 230 & $202 / 112$ \\
6 & 235 & $160 / 120$ & 235 & $190 / 140$ \\
\hline
\end{tabular}

\begin{tabular}{ccccccc}
\hline $\begin{array}{c}\text { Patient } \\
\text { no. }\end{array}$ & $\begin{array}{c}\text { 1 month post-captopril } \\
\text { Plasma } \\
\text { creatinine }\end{array}$ & $\begin{array}{c}\text { Out-patient } \\
\text { BP }\end{array}$ & \multicolumn{2}{c}{$\begin{array}{c}\text { 3 months post-captopril } \\
\text { Plasma } \\
\text { creatinine }\end{array}$} & $\begin{array}{c}\text { Out-patient } \\
\text { BP }\end{array}$ & \multicolumn{2}{c}{$\begin{array}{c}\text { 6 months post-captopril } \\
\text { Plasma } \\
\text { creatinine }\end{array}$} & $\begin{array}{c}\text { Out-patient } \\
\text { BP }\end{array}$ \\
\hline 1 & 680 & $130 / 90$ & 700 & $150 / 90$ & 650 & $130 / 85$ \\
2 & 360 & $150 / 90$ & 430 & $140 / 90$ & 505 & $140 / 92$ \\
3 & 814 & $180 / 100$ & 847 & $160 / 100$ & 851 & $150 / 100$ \\
4 & 757 & $190 / 110$ & 714 & $178 / 102$ & 697 & $142 / 90$ \\
5 & 220 & $160 / 90$ & 210 & $170 / 100$ & 237 & $160 / 90$ \\
6 & 254 & $136 / 98$ & 241 & $170 / 106$ & 236 & $136 / 90$ \\
\hline
\end{tabular}

